\title{
DIGITALCOMMONS
}

@WAYNESTATE-

Wayne State University

Human Biology Open Access Pre-Prints

WSU Press

7-1-2020

\section{Indigenizing Restoration: Indigenous Lands before Urban Parks}

Jessica Hernandez

University of Washington

Kristina Vogt

University of Washington

Follow this and additional works at: https://digitalcommons.wayne.edu/humbiol_preprints

\section{Recommended Citation}

Hernandez, Jessica and Vogt, Kristina, "Indigenizing Restoration: Indigenous Lands before Urban Parks" (2020). Human Biology Open Access Pre-Prints. 171.

https://digitalcommons.wayne.edu/humbiol_preprints/171

This Article is brought to you for free and open access by the WSU Press at DigitalCommons@WayneState. It has been accepted for inclusion in Human Biology Open Access Pre-Prints by an authorized administrator of DigitalCommons@WayneState. 


\section{Indigenizing Restoration: Indigenous Lands before Urban Parks}

Jessica Hernandez ${ }^{*}$ and Kristiina A. Vogt1

1School of Environmental and Forest Sciences, College of Environment, University of Washington, Seattle, Washington, USA.

*Correspondence to: Jessica Hernandez, School of Environmental and Forest Sciences, College of Environment, University of Washington, Anderson Hall, Box 352100, Seattle, WA 98195 USA. E-mail: jhernan@uw.edu.

Short Title: Indigenizing Restoration: Indigenous Lands before Urban Parks

KEY WORDS: ECO-COLONIALISM, KINCENTRIC ECOLOGY, ENVIRONMENTAL NARRATIVES, INDIGENOUS PEOPLES, SETTLER COLONIALISM, CLIMATE CHANGE, INDIGENIZING.

\footnotetext{
Abstract

Climate change and human activities continue to result in negative environmental impacts that alter land productivity, ecosystem health, and their potential land-uses. However, these environmental impacts are being addressed through land restoration frameworks that do not include the robust narrative on the links between land and Indigenous peoples. This link between land and Indigenous peoples is not visible in restoration frameworks due to the linearity these frameworks follow and their deep roots in western science. In this paper, we contend that
} 
restoration projects must incorporate three indicators that re-evaluates restoration from an Indigenous lens. Through a literature review \& our ongoing restoration project, we identify three major indicators that are important to incorporate in restoration. These indicators are ecocolonialism, kincentric ecology, and environmental narratives. After discussing the three indicators in our paper, we apply these indicators to provide the historical context of our ongoing field site, Daybreak Star Indian Cultural Center located at Discovery Park. Discovery Park is the largest urban park located in Seattle, Washington. We conclude that including these three indicators into restoration frameworks not only indigenizes restoration, but can also help us create more effective solutions to environmental problems persisting for decades in unhealthy ecosystems.

Pre-print version. Visit http://digitalcommons.wayne.edu/humbiol/ after publication to acquire the final version. 
Climate change and human impacts are known to impact Indigenous peoples first. Indigenous peoples are already confronting the impacts of climate change and human impacts such as sea level rise that results in flooding for coastal communities, ocean acidification that impacts the shellfish and other sustenance aquatic foods, and many more (Abate, R., 2013, Ramos-Castillo, A., et.al., 2017, \& Reo, N.J., et. al. 2017). Climate change coupled with the impacts of settler colonialism introduced over-exploitative and extractive methods onto Indigenous lands. As a result, this makes Indigenous peoples vulnerable to climate injustice (Roosvall, A, et.al., 2018). It is important to mention that Indigenous peoples were environmental stewards that have effectively managed their lands to sustain their livelihoods-pre- and post-colonialism (Hossain, K., 2012, Tsosie, R. 2013, \& Marchand, M., et. al. 2020). This includes continuing to manage their lands as climate change continues to exacerbate their land and water ecosystems. Despite Indigenous people representing about $5 \%$ of the world's population and occupying $20 \%$ of the world's land area, they manage and protect $80 \%$ of the world's biodiversity (Cochran, P., et.al., 2013 \& Stevens, S., 2014). This is one of the major reasons why incorporating Indigenous peoples in restoration frameworks is crucial and important.

Unfortunately, Indigenous peoples continue to be left out from the restoration discourse due to the linearity these frameworks follow. Since restoration frameworks are developed by western knowledge systems, they do not include the holistic lens Indigenous peoples followed and continue to follow. These systems continue to ignore Indigenous ways of knowing because they are heavily rooted in the scientific method of hypothesis testing (Kronik, J., et.al., 2010 \& Berglund, B., et. al., 2013). This scientific philosophy requires forming knowledge that is validated through western credentials, thus dismissing Indigenous peoples. Indigenous peoples 
have a long-history of first-hand observations and knowledge formations to their natural resources and environment.

\section{Restoration in National and Urban Parks}

In order to further understand the exclusion of Indigenous peoples from restoration frameworks, we must revisit the history of national and urban parks. National and urban parks have a long history of excluding Indigenous peoples since their establishment. This is due to the ideologies introduced by manifest destiny and settler colonialism. During the 1870 s and 1880s, when Yellowstone National Park was created, Indigenous peoples were forcibly removed and relocated. Following Yellowstone's establishment, President Theodore Roosevelt signed the Antiquities Act in 1906 (Lee, R.F., 1970). This Antiquities Act gave presidents the authority to create national monuments to preserve areas of natural or historic interest on public lands. The purpose of the Act was to protect prehistoric Indigenous ruins and artifacts. It also served to preserve pristine wilderness and nature, mostly fauna and flora. The protection of pristine wilderness and the natural elements of this setting - excluding humans, is what marked the establishment of the colonial restoration framework. National and urban parks mostly operate under three restoration frameworks. These are known as extractive, aesthetic, and biotelic restoration (Maller, C., et. al. 2008).

Extractive restoration focuses on the products and revenue certain parks can provide. This ranges from natural forest products (e.g. timber) to recreational uses (e.g. hiking, social trails, etc.) (Miller, M., et. al., 2014). Biotelic restoration focuses on the protection of species and the habitat and the exclusion of human interaction in such settings (Crowe, D.M., et. al. 1995). Aesthetic restoration — which was inspired by the aesthetic art movement — aims to preserve 
nature's beauty for the enjoyment of humans (Higham, J., et. al., 2008). All of these three restoration frameworks were created after Indigenous peoples were removed from their lands. This removal is what created this separation between humans and nature that is still present today in restoration paradigms. However, humans — in particular Indigenous peoples — are essential to restoration, especially in a changing climate. Indigenous knowledge systems can create more effective solutions than the current restoration frameworks management agencies incorporate. Recent ecological research has also concluded that when Indigenous peoples manage their forests and lands, land productivity is higher, ecosystems are healthier, and resource scarcity is a less likely to occur (Waller, D. et. al., 2018). This solidifies the importance of incorporating Indigenous peoples in land restoration frameworks, especially in urban and national parks commonly utilized by the public.

\section{Three Indicators to Indigenize Restoration}

In order to Indigenize restoration, Indigenous peoples do not require a seat at the table, they must become the head of the table. This is because just providing them a seat at the table leads to the continued stereotyping Indigenous peoples face in the environmental discourse. One of the most known stereotypes is of the ecological noble savage (Hames, R., 2007\& Aftandilian, D., 2011). This stereotype portrays Indigenous peoples as majestic creatures, as once described by early environmental western explorers, that are in tune with nature (Ellingson, T., 2001). In order to avoid these stereotypes, Indigenous peoples need to be granted the leadership roles. This is how we define Indigenizing in our paper. Indigenizing restoration refers to shifting restoration frameworks to not just include Indigenous peoples, but transforming these frameworks entirely to remove them from the colonial structures they were founded on. Indigenizing restoration 
facilitates the integration of community-based approaches, cultural protocols (e.g. prayers and songs when introducing a new plant relative into space), and community involvement (e.g. work parties). Through our literature review and ongoing restoration project, we identify three indicators to Indigenize restoration (Figure 1). These indicators include: eco-colonialism, kincentric ecology, and environmental narratives.

First Indicator: Eco-Colonialism: The history of how the relationships between land and Indigenous peoples that have been altered and impacted as a result of settler colonialism, is known as eco-colonialism. Eco-Colonialism is a history that weaves together the ecological knowledge and historical timeline of the landscape management practices of Indigenous peoples on their ancestral lands.

Second Indicator: Kincentric Ecology: Kincentric ecology (Figure 2) refers to the kinships, relationships, and cultural connections Indigenous peoples have to land (Simmons, E., 2013 \& Nelson, M., et.al., 2018). This approach can help us create more effective restoration frameworks and paradigms instead of having environmental problems persisting for decades in unhealthy ecosystems. Kincentric ecology intersects with Indigenous peoples and their relationship to the land. This is why it is important to integrate restoration frameworks to help us create more holistic solutions essential to our lands as we continue to experience climate change impacts. Since kincentric ecology emphasizes the physical and spiritual connection to land, it is important to respect these complex-bonds that are present among the Indigenous community (Turner, N., 2005). 
Third Indicator: Environmental Narratives: First-hand observations and knowledge formations of our local environment are also known as environmental narratives (Evering, B., 2019). Environmental narratives weave together Indigenous ways of knowing that can serve as testaments to the relationship Indigenous peoples have with land and how these have been altered due to settler colonialism (Peterson, R., 2000). It is important to note that Indigenous ways of knowing is comprised of many knowledge systems - as Indigenous peoples are not monolithic cultures. Their knowledge is place-based, therefore, their unique environments is what shapes it. Also settler colonialism impacted their knowledge systems when they were forced to relocate or were displaced from their ancestral homelands.

Our three indicators Indigenize restoration because they also link restoration to resilience - which is integral to ecosystems and Indigenous communities, especially as climate change continues to exacerbate lands degradation. Indigenous resilience has been a common topic discussed by many Indigenous scholars (Berkes, F., et.al., 2003 \& Lin, S., 2019). Resilience was first adapted to socio-ecological frameworks by Dr. Fikret Berkes (Berkes, F., 2017). Dr. Berkes understood that resilience was a concept necessary to explore and integrate into socio-ecological systems in order to avoid another tragedy of commons (Olsson, P., et.al., 2004). The tragedy of commons is what results when one natural resource is depleted, as we have witnessed with salmon species in the state of Washington. And overharvest and overextraction of a natural resource at a faster rate than they can be replenished is what depletes and collapses entire ecosystems (Hale, W., 1971). Recent research has coupled the tragedy of commons with ecological tipping points (Wiens, J., 2016). Both apply and integrate social, economic, and environmental factors. In Figure 3, we demonstrate how the tragedy of commons 
can be applied to invasive plant species tipping points in the 20 acres leased to Daybreak Star Indian Cultural Center in Discovery Park—our case study for our ongoing restoration project. Indigenous people's ability to preserve important elements of their culture through their Indigenous knowledge and oral history demonstrates their resiliency. This is why their knowledge systems are able to adapt to new climates, spaces, and environments. Their adaptability and resiliency are the main reasons why Indigenous peoples' teachings can serve as solutions to environmental degradation and crisis we currently face in a changing climate (Aftadilian, D., 2011). Climate change is resulting in changes to our environments and spaces, and thus, if we want to adapt and mitigate climate change, Indigenous knowledge should be at the center of restoration frameworks. Often times, we speak about giving Indigenous peoples a seat at the table, but it is imperative that they become the "head of the table". This allows them to lead their own conservation and restoration initiatives. We cannot ignore how Indigenous peoples are already facing the impacts of climate change and how restoration frameworks may or may not work. While climate change continues to be an inconvenient truth to some, climate change is a deadly and life-changing reality to Indigenous peoples (Wildcat, D., 2009).

\section{Links between Environmental Racism and Our Urban Park Case Study}

It is important to acknowledge the history of urban parks - as entities of natural spaces — were built to provide a pristine natural setting in cities (Maller, C., et.al., 2009). Most parks were established and created in urban environments following western policies, management, and evidence-based science practices. As a result, urban parks have a long history of excluding communities of color - in particular Indigenous communities (MacDonald, D., 2018). This trend of environmental racism continues to place the greatest environmental impacts on communities 
of color. It also justifies why power plants, factories, and other environmental hazards and polluting agencies are built in close proximity to where these communities of color reside (Pulido, L., 2015).

Our case study for our ongoing restoration project takes place at Daybreak Star Indian Cultural Center, located at Discovery park. Daybreak Star Indian Cultural Center serves as an urban cultural center for Native Americans in the Seattle area (Seattle, et. al., 1974 \& Monthan, G., et. al., 1978). It was officially built and opened in 1977—seven years after the occupations of these lands by Urban Indigenous activists. When the military base was given to Seattle Parks and Recreation, one-hundred Urban Indigenous peoples under the leadership of Bernie Whitebear led a peaceful resistance movement to reclaim these lands (Reyes, L., 2006). Due to the media and celebrity attention this movement received, Seattle proceeded to lease 20 out of the 534 acres of those lands to the Urban Indigenous peoples (Parham, V., 2018). They were able to lease this from Seattle Parks and Recreation under the auspices of the United Indians of All Tribes Foundation - the nonprofit that oversees Daybreak Star Indian Cultural Center. It is important to reemphasize that while Discovery Park is 534 acres in size, Daybreak Star Indian Cultural Center was only given 20 acres of land a through 99-year lease signed with Seattle Parks and Recreation.

When diving into the history of urban parks within the Seattle Metropolitan Area context, it is important to note that Indigenous peoples experienced environmental racism by being banned from entering the city through an enactment law. This ordinance enacted on February 7 , 1865, prevented and made it unlawful for Native Americans to set foot in the city limits - thus removing Indigenous peoples from the environmental discourse that emerged in Seattle (Buerge, D., 1992). Seattle was built for the settlers and not the original peoples of these lands. Ironically, 
the city of Seattle tries to erase or hide the oppression enacted on Indigenous peoples in its history. It is highly advertised that the city was named after Chief Sealth-a Suquamish and Duwamish chief (Buerge, D., 1992). However, this city does not acknowledge that he was not even allowed to step foot within the city proximities. If this city continues to glorify Coast Salish cultures just for capitalistic reasons (i.e. tourism), it should also include the Indigenous peoples of these lands and urban Natives in the environmental discourse that surrounds the environmental policies, laws, and regulations for the state of Washington.

During the enactment of the 1865 ordinance, Indigenous peoples were being forced into reservations based on an agreement that was made during the 1855 Treaty of Point Elliott. This treaty was not ratified until 1859 and even after its ratification, it took several years for any infrastructures to be built in reservations (i.e. towns, government systems, etc.). Indigenous peoples were forced to leave their native and ancestral lands-landscapes they had managed for centuries. Even though this ordinance was dismantled in 1867— when the government of Seattle was dissolved, tensions continued against Indigenous peoples. The City of Seattle was rapidly urbanizing during this time and this contributed to the further environmental displacement of Indigenous peoples. This included the continued destruction of important landscapes to Indigenous peoples, including the Herring's House in 1893 — where Chief Seattle lived. Throughout this part of history, we can conclude that there was a lot of environmental racism against Indigenous peoples. The question to ask today is has anything changed for Indigenous peoples in the state of Washington?

This twenty-two-year gap between the formation of Seattle's first urban park and its exclusion of any indigenous people from Seattle demonstrates the continuing racism that was embedded in this city and its inhabitants against Indigenous peoples going back to the time when 
Seattle created its first urban park. This means urban parks were not designed to serve Indigenous peoples. This is rooted in the philosophy that Indigenous peoples had no rights to lands from which they had been dispossessed and the acceptance of Captain Richard Pratt's belief that "Kill the Indian, and Save the Man," (Zalcman, D., 2016). This view propagated many of the forceful assimilation tactics that were used against Indigenous communities (Marchand, M., et. al. 2020).

However, Indigenous peoples continued to resist against settler colonialism practices rooted in foreign policies and land claims on native lands. Today, Seattle Parks and Recreation oversees 400 urban parks. One of these urban parks was the setting of the historical Indigenousled activist movement. This movement took place during the early establishment of Discovery Park. The history of Discovery Park is very unique as all 534 acres of this land used to be a military base, Fort Lawton (Kiley, D. et. al., 1974). Fort Lawton was built in 1900 and was named after Henry Ware Lawton - a veteran who served in the American Civil War, the Indian Wars, and Spanish-American War. However, in 1970, the army declared all 534-acres of Fort Lawton as surplus land and granted this land to Seattle Parks and Recreation. Eventually, this land was named Discovery Park.

Given that Discovery Park used to be a military base, the lands were environmentally pollution as a result of military activities and construction. These military activities, combined with the urbanization of its nearby Magnolia neighborhood, has extremely altered what once used to be lands formed by glacial deposits and included rivers where salmon migrated to their spawning grounds (Ashworth, A., et. al. 2014). While land restoration forces us to focus on invasive species and integrating more native species, we have to also incorporate the ecocolonialism practices on this land to ensure that it heals holistically. This means that there should 
be a shift from today's linear approach to one that is landscape-based and links water and land using the holistic lens of Indigenous people as part of landscape restoration. Despite Indigenous peoples and organizations being physically present at Discovery Park, they are not consulted by Seattle Parks and Recreation when designing and implementing their restoration or conservation practices (Thompson et al. 2015). This is no surprise as urban parks in Seattle are rooted in postcolonial history that did not allow Native peoples to step foot in this city for decades. Since the lease was signed in 1970, Seattle Parks and Recreation has not had a major emphasis on implementing restoration or conservation projects on the 20 -acres leased to the Daybreak Star Indian Cultural Center. The lease does not define who has the responsibility to conduct restoration and conservation work at Daybreak Star Indian Cultural Center.

However, Discovery Park already manages conservation and restoration projects on the entire 534-acres that make up Discovery Park. Therefore, using a landscape lens on the 20 acres leased to Indigenous communities suggests that the Seattle Parks and Recreation is an important manager to integrate into any restoration and conservation efforts for the entire Park. However, these activities need to include the knowledge held by the Indigenous people who lived on these land and continue to use a holistic landscape approach to their land management. Such an approach has been shown to result in resilient lands and water which is essential for conserving and restoring highly altered lands that are less healthy.

\section{Restoration Framework Utilized in Discovery Park by Seattle Parks and Recreation}

Seattle Parks and Recreation's restoration and conservation efforts focus on vegetation restoration based on scientific evidence that does not include the landscape cultural attributes held by the Indigenous people who lived on these lands and managed them using a holistic 
landscape approach. A vegetation restoration focus follows a linear approach because it focuses on removing invasive or non-native plant species and planting native species in its place

(Quillérou, E.J., et. al. 2012 \& Aronson, J., et. al., 2017). It focuses management to split the land into smaller land-plots derives from the western notion of a garden — where a small piece of land is restored and nearby land is ignored (Daniels, J., et. al., 2016).

Restoring land through this garden-gaze prevents us from creating a holistic conservation framework that addresses the entire park as opposed to smaller portions of it. Indigenizing restoration allows us to create and implement more holistic conservation and restoration initiatives to heal these severely altered lands. We need to start looking at the entire landscape as every non-living and living species in this park is an integral component of healing these lands through restoration and conservation practices. This relationship between all living and nonliving things and humans is known as kincentric ecology (Salmón, E., 2000).

Through indigenizing conservation and restoration, we also address some of the layers embedded through settler colonialism present on Indigenous lands. For the Coast Salish peoples, Discovery Park was important for them because it is the location of their ancestral burial sites and migration routes to salmon. By integrating kincentric ecology and acknowledging the ongoing eco-colonialism and environmental narrative important to specific landscapes, this also allows Indigenous peoples to practice their traditional environmental customs and life patterns that are not integrated or taken into account in land restoration and conservation work (Wehi, P., et. al., 2017). Recent research acknowledges how traditional knowledge systems can help repair the damage that has been done in the land (Wehi, P., et. al., 2017).

\section{Next Steps and Conclusion}

Pre-print version. Visit http://digitalcommons.wayne.edu/humbiol/ after publication to acquire the final version. 
The negative environmental impacts that alter land productivity, ecosystem health and the uses of urban parks are being addressed through restoration and conservation frameworks that are not as effective. This is due to its focus on vegetation restoration and its exclusion of eco-colonialism acknowledgment and kincentric ecology. In our case study, the restoration and conservation frameworks must be indigenized due to the importance of this landscape not only to Indigenous peoples but the previous salmon populations that used to frequent it. Given that Discovery Park is also the location for Daybreak Star Indian Cultural Center, we advocate for conservation and restoration frameworks for urban parks designed by indigenous people who have a holistic approach to land and water management. Our continued collaborations, with Indigenous people on the restoration and conservation of the 20 acres leased to Daybreak Star Indian Cultural Center, will allow us to continue adapting our indigenized framework to produce approaches where the lands can adapt to a changing climate.

Received 20 March 2020; accepted for publication 4 May 2020.

Pre-print version. Visit http://digitalcommons.wayne.edu/humbiol/ after publication to acquire the final version. 


\section{Literature Cited}

Abate, R., and E. A. Kronk Warner, eds. 2013. Climate Change and Indigenous Peoples:

The Search for Legal Remedies. Cheltenham, UK; Northampton, MA: Edward Elgar.

Aftandilian, D. 2011. What other Americans can and cannot learn from Native American environmental ethics. Worldviews 15:219-246.

Aronson, J., J. Blignaut, and T. Aronson. 2017. Conceptual frameworks and references for landscape-scale restoration: Reflecting back and looking forward. Ann. Mo. Bot. Gard. 102:188-200.

Ashworth, A., and R. Nelson. 2014. The paleoenvironment of the Olympia beds based on fossil beetles from Discovery Park, Seattle, Washington, U.S.A. Quat. Int. 341:243-254.

Berglund, B., L. Hallgren, and Á. L. Aradóttir. 2013. Cultivating communication: Participatory approaches in land restoration in Iceland. Ecol. Soc. 18:35.

Berkes, F. 2017. Environmental governance for the Anthropocene? Social-ecological systems, resilience, and collaborative learning. Sustainability 9:1232.

Berkes, F., J. Colding, and C. Folke, eds. 2003. Navigating Social-ecological Systems: Building Resilience for Complexity and Change. New York: Cambridge University Press.

Buerge, D. 1992. Chief Seattle. Seattle, WA: Sasquatch Books.

Cochran, P., O. Huntington, C. Pungowiyi et al. 2013. Indigenous frameworks for observing and responding to climate change in Alaska. Clim. Change 120:557-567.

Crowe, D. M., and J. Shryer. 1995. Eco-colonialism. Wildl. Soc. Bull. 23:26-30.

Daniels, J. M., W. Brinkley, and M. D. Paruszkiewicz. 2016. Urban Forest Restoration Cost Modeling: A Seattle Natural Areas Case Study. General technical report PNW-GTR-921. 
Portland, OR: United States Department of Agriculture, Forest Service, Pacific Northwest Research Station.

Ellingson, T. 2001. The Myth of the Noble Savage. Berkeley, CA: University of California Press.

Evering, B. 2019. Know*ledge constellations and re*constellating: Narratives to inform Indigenous-and-environmental education. Environ. Educ. Res. 25:151-152.

Hale, W., and D. F. Wittusen. 1971. World Fisheries: A "Tragedy of the Commons?" Monograph Series in Public Affairs, No. 4: Woodrow Wilson Association. Princeton, NJ: Woodrow Wilson School of Public and International Affairs, Princeton University.

Hames, R. 2007. The ecologically noble savage debate. Annu. Rev. Anthropol. 36:177-190. Higham, J., and M. Lück. 2008. Marine Wildlife and Tourism Management Insights from the Natural and Social Sciences. Cambridge, MA: CABI.

Hossain, K. 2012. Globalization, climate change, and Indigenous peoples in the Arctic. In Globalization, International Law, and Human Rights, J. F. Addicott, J. H. Bhuiyan, and T. M. R. Chowdhury, eds. Oxford, UK: Oxford University Press.

Kronik, J., and D. Verner. 2010. Indigenous Peoples and Climate Change in Latin America and the Caribbean. Washington, D.C.: World Bank.

Lee, R. F. 1970. Antiquities Act of 1906. Washington, D. C.: National Park Service and the Department of the Interior.

Lin, S. 2019. Building resilience through ecosystem restoration and community participation: Post-disaster recovery in coastal island communities. Int. J. Disaster Risk Reduct. 39:101249.

MacDonald, D. 2018. Before Yellowstone: Native American Archaeology in the National Park. Seattle, WA: University of Washington Press. 
Maller, C., M. Townsend, L. St Leger et al. 2009. Healthy parks, healthy people: The health benefits of contact with nature in a park context. George Wright Forum 26:51-83.

Marchand, M. E., K. A. Vogt, R. Cawston et al. 2020. The Medicine Wheel: Environmental Decision-Making Process of Indigenous Peoples. East Lansing, MI: Michigan State University Press.

Miller, M., R. Carter, S. Walsh et al. 2014. A conceptual framework for studying global change, tourism, and the sustainability of iconic national parks. George Wright Forum 31:256269.

Monthan, G., and D. Monthan. 1978. Daybreak Star Center. Am. Indian Art Mag. 3:28-34.

Nelson, M., and D. Shilling, eds. 2018. Traditional Ecological Knowledge: Learning from Indigenous Practices for Environmental Sustainability. 1st ed. Cambridge, UK: Cambridge University Press.

Olsson, P., C. Folke, and F. Berkes. 2004. Adaptive comanagement for building resilience in social-ecological systems. Environ. Manage. 34:75-90.

Parham, V. 2018. Pan-Tribal Activism in the Pacific Northwest: The Power of Indigenous Protest and the Birth of Daybreak Star Cultural Center. Lanham, MD: Lexington Books.

Peterson, R. 2000. Conversations in the Rainforest: Culture, Values, and the Environment in Central Africa. Boulder, CO: Westview Press.

Pulido, L. 2015. Geographies of race and ethnicity 1: White supremacy vs white privilege in environmental racism research. Prog. Hum. Geogr. 39:809-817.

Quillérou, E., and R. Thomas. 2012. Costs of land degradation and benefits of land restoration: A review of valuation methods and suggested frameworks for inclusion into policy-making. CAB Rev. Perspect. Agric. Vet. Sci. Nutr. Nat. Resour. 7:1-12. 
Ramos-Castillo, A., E. Castellanos, and J. Galloway McLean. 2017. Indigenous peoples, local communities and climate change mitigation. Clim. Change 140:1-4.

Reo, N. J., K. Whyte, D. Ranco et al. 2017. Invasive species, indigenous stewards, and vulnerability discourse. Am. Indian Q. 41:201-223.

Reyes, L. 2006. Bernie Whitebear: An Urban Indian's Quest for Justice. Tucson, AZ: University of Arizona Press.

Roosvall, A., and M. Tegelberg. 2018. Media and Transnational Climate Justice: Indigenous Activism and Climate Politics. New York: Peter Lang Publishing.

Salmón, E. 2000. Kincentric ecology: Indigenous perceptions of the human-nature relationship. Ecol. Appl. 10:1,327-1,332.

Simmons, E. 2013. Indigenous Earth: Praxis and Transformation. Penticton, BC: Theytus Books.

Stevens, S. 2014. Indigenous Peoples, National Parks, and Protected Areas: A New Paradigm Linking Conservation, Culture, and Rights. Tucson, AZ: University of Arizona Press.

Thompson, S., Kootenai Culture Committee, and Pikunni Traditional Association. 2015. People Before the Park: The Kootenai and Blackfeet Before Glacier National Park. Helena, MT: Montana Historical Society Press.

Tsosie, R. 2013. Climate change and indigenous peoples: Comparative models of sovereignty. Tulane Environ. Law J. 26:239-257.

Turner, N. 2005. The Earth's Blanket: Traditional Teachings for Sustainable Living. Seattle, WA: University of Washington Press. 
Urban Indian Health Commission. 2007. Invisible Tribes: Urban Indians and Their Health in a Changing World. Seattle, WA: Urban Indian Health Commission, Robert Wood Johnson Foundation, and the Urban Indian Health Institute.

Waller, D., and N. Reo. 2018. First stewards: Ecological outcomes of forest and wildlife stewardship by indigenous peoples of Wisconsin, USA. Ecol. Soc. 23:45.

Wehi, P., and J. Lord. 2017. Importance of including cultural practices in ecological restoration. Conserv. Biol. 31:1,109-1,118.

Wiens, J. 2016. Ecological Challenges and Conservation Conundrums: Essays and Reflections for a Changing World. West Sussex, UK; Hoboken, NJ: John Wiley \& Sons.

Wildcat, D. 2009. Red Alert! Saving the Planet with Indigenous Knowledge. Golden, CO: Fulcrum Publishing.

Zalcman, D. 2016. "Kill the Indian, save the man": On the painful legacy of Canada's residential schools. World Policy J. 33:72-85.

Pre-print version. Visit http://digitalcommons.wayne.edu/humbiol/ after publication to acquire the final version. 


\section{Figure Captions}

Figure 1. Indigenizing Restoration Indicators.

Figure 2. Kincentric Ecology Indigenous Model.

Figure 3. The Tragedy of the Commons.

Pre-print version. Visit http://digitalcommons.wayne.edu/humbiol/ after publication to acquire the final version. 


\section{Figure 1.}

\begin{tabular}{|c|c|c|c|}
\hline Indigenizing Restoration & $\begin{array}{l}\text { Indicator 1: } \\
\text { Kincentric Ecology } \\
\text { Relationship between all } \\
\text { living and non-living things } \\
\text { and humans }\end{array}$ & $\begin{array}{l}\text { Indicator 2: } \\
\text { Environmental Narratives } \\
\text { Weave together Indigenous } \\
\text { ways of knowing that can } \\
\text { serve as testaments to the } \\
\text { relationship Indigenous } \\
\text { peoples have with land and } \\
\text { how these have been altered } \\
\text { due to settler colonialism }\end{array}$ & $\begin{array}{c}\text { Indicator 3: } \\
\text { Eco-Colonialism } \\
\text { History that weaves together } \\
\text { the ecological knowledge and } \\
\text { historical timeline of the } \\
\text { landscape management } \\
\text { practices of Indigenous } \\
\text { peoples on their ancestral } \\
\text { lands }\end{array}$ \\
\hline
\end{tabular}


Figure 2.

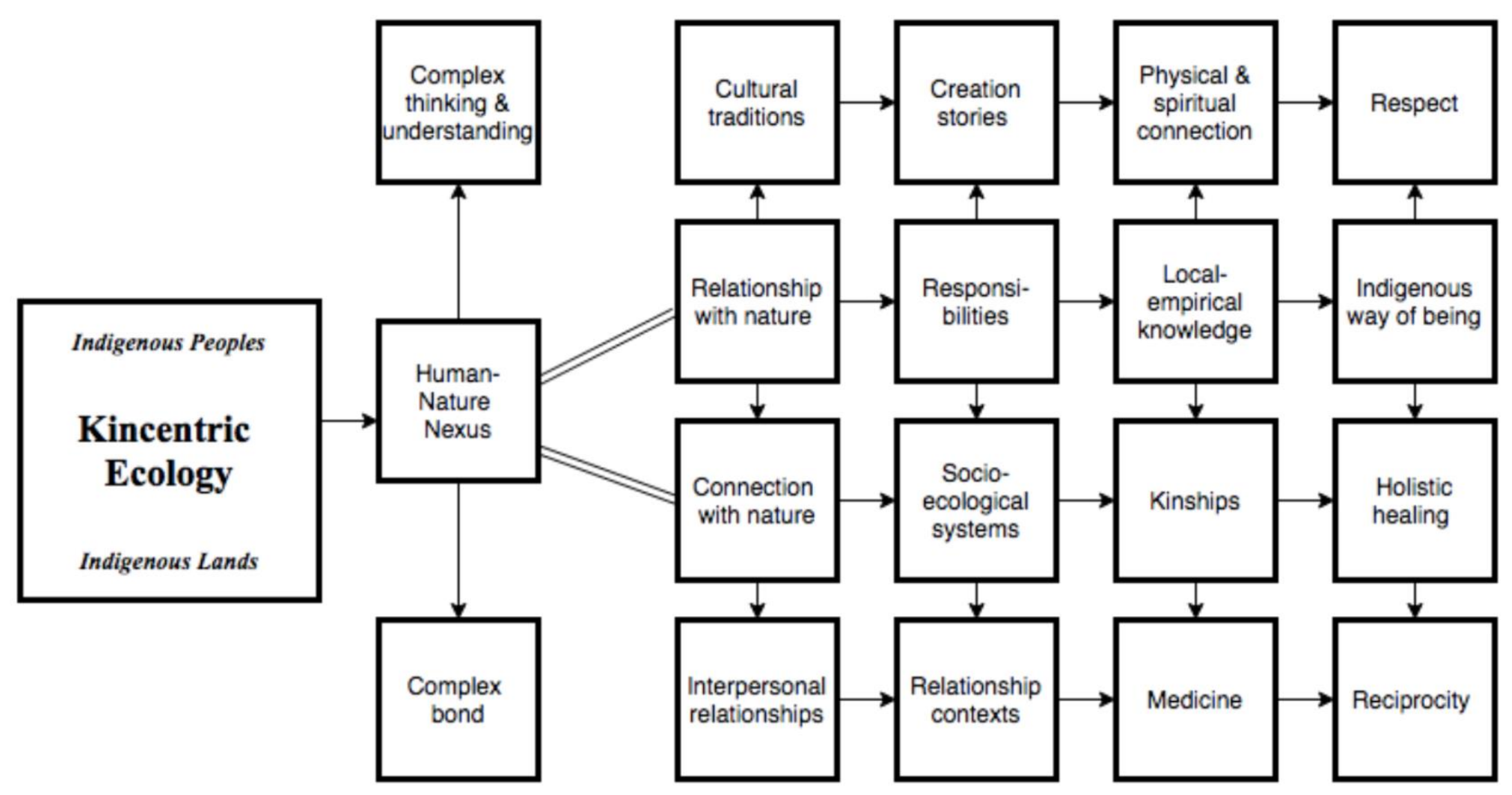




\section{Figure 3.}

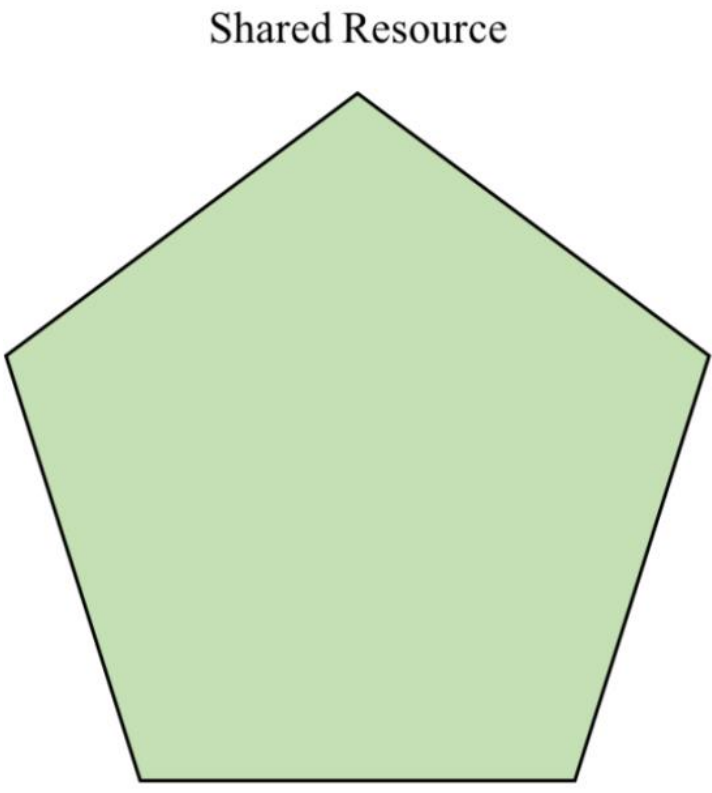

20 acres leased to Daybreak Star.

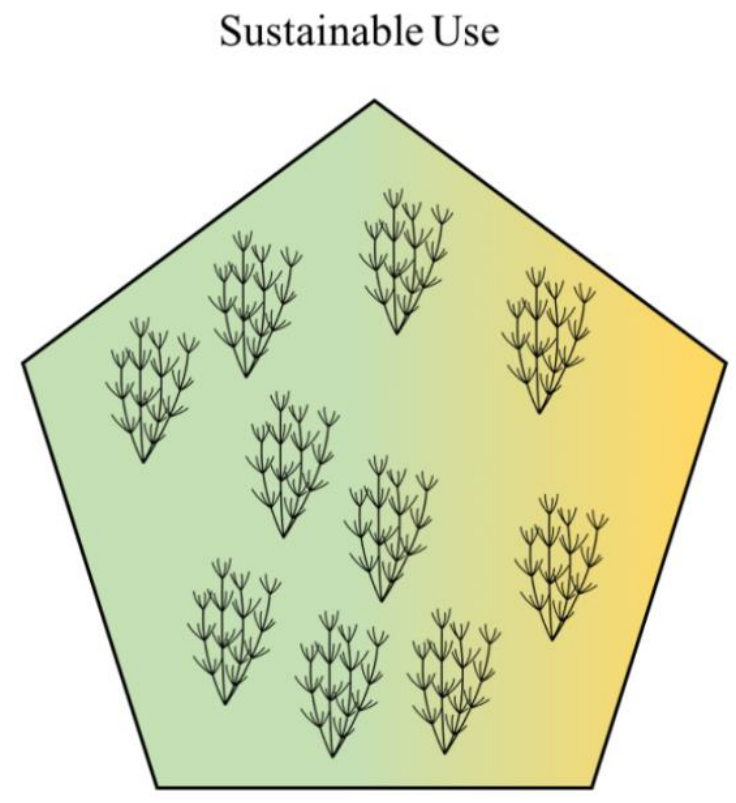

10 invasive blackberry species. Carrying capacity.
Depleted Resources

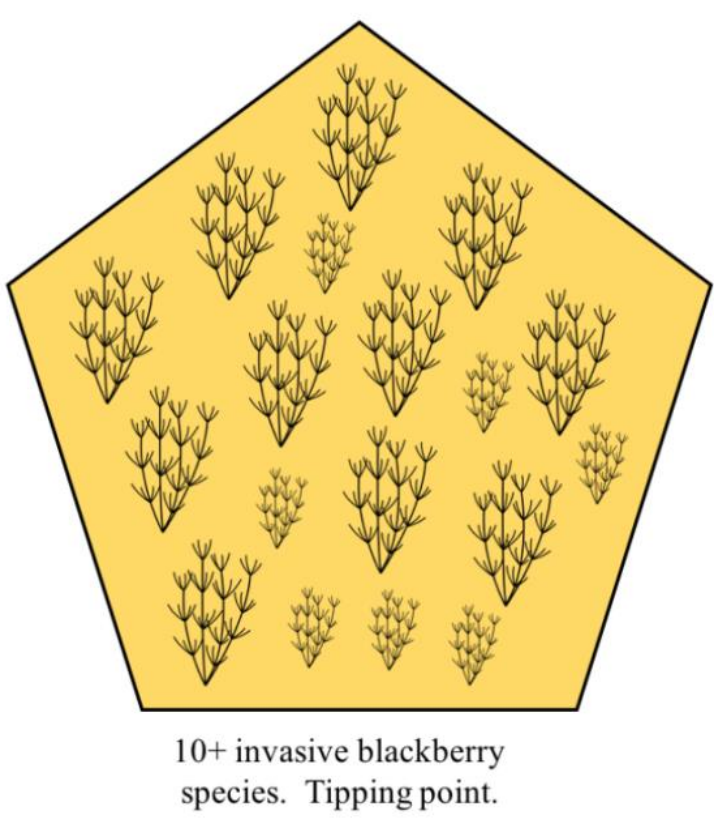

